\title{
Gene Expression Profiling of the Paracrine Effects of Uterine Natural Killer Cells on Human Endometrial Epithelial Cells
}

\author{
Xin Gong, ${ }^{1}$ Zhenzhen Chen, ${ }^{2}$ Yanxia Liu, ${ }^{1}$ Qiudan Lu, ${ }^{1}$ and Zhe Jin ${ }^{1}$ \\ ${ }^{1}$ Reproductive Endocrinology Centre, Dongfang Hospital of Beijing University of Chinese Medicine, No. 6 Fangxingyuan 1 Qu, \\ Fengtai District, Beijing 100078, China \\ ${ }^{2}$ School of Chinese Materia Medica, Beijing University of Chinese Medicine, No. 6 Zhonghuan South Road, Wangjing, \\ Chaoyang District, Beijing 100102, China
}

Correspondence should be addressed to Zhe Jin; zjin0129@163.com

Received 19 December 2013; Accepted 18 February 2014; Published 26 March 2014

Academic Editor: F. Xavier Donadeu

Copyright $(\odot 2014$ Xin Gong et al. This is an open access article distributed under the Creative Commons Attribution License, which permits unrestricted use, distribution, and reproduction in any medium, provided the original work is properly cited.

\begin{abstract}
The endometrium contains a population of immune cells that undergo changes during implantation and pregnancy. The majority of these cells are uterine natural killer (uNK) cells; however, it is unclear how these cells interact with endometrial epithelial cells. Therefore, we investigated the paracrine effects of the uNK cell-secretion medium on the gene expression profile of endometrial epithelial cells in vitro through microarray analysis. Our results, which were verified by qRT-PCR and western blot, revealed that soluble factors from uNK cells alter the gene expression profiles of epithelial cells. The upregulated genes included interleukin15 (IL-15) and interleukin-15 receptor alpha (IL-15RA), which result in a loop that stimulates uNK cell proliferation. In addition, vascular endothelial growth factor C (VEGF-C) and chemokine (C-X-C motif) ligand 10 (CXCL-10) were also determined to be upregulated in epithelial cells, which suggests that uNK cells work synergistically with epithelial cells to support implantation and pregnancy. In addition, oriental herbal medicines have been used to treat infertility since ancient times; however, we failed to find that $\mathrm{Zi}$ Dan Yin can regulate these endometrial paracrine effects.
\end{abstract}

\section{Introduction}

In the human endometrium, uterine leucocytes undergo cyclic changes during the menstrual cycle. Uterine adaptation to pregnancy includes highly regulated immune cell trafficking [1]. According to recent studies, uterine natural killer (uNK) cells are an in vivo factor that contributes to the pathological elongation of the window of endometrial receptivity [2]. The genetic deficiency of uNK cells results in a lack of remodeling of the uterine vasculature, leading to hypertrophied vascular media, swollen endothelial cells, and narrow vessel lumens [3]. Abnormal activation and numbers of uNK cells have been implicated in pregnancy complications [4].

uNK cells are the most abundant leucocytes during the implantation window and early pregnancy [5]. This sharp increase is likely due to the proliferation of existing uNK cells [6-8]. Hormonal effects may control this proliferation. However, to date, progesterone receptors have not been localized on these cells [9]; therefore, it has been proposed that progesterone may exert its effects on uNK cells indirectly via cytokines, such as interleukin-15 (IL-15), and other soluble factors $[8,10]$. A previous study indicated that the paracrine communication between uterine leucocytes $(>85 \% \mathrm{uNK})$ and uterine stromal cells can upregulate IL-15 and interleukin-15 receptor alpha (IL-15RA) to induce the proliferation of uNK cells and contributes to the support of trophoblast migration during implantation [11].

uNK cells are resident throughout the endometrium at the time of conception and throughout early pregnancy. Although uNK cells predominantly localize to the uterine stroma and the surrounding areas of the spiral arteries, Matrigel-supported cocultures of endothelial cells and uNK cells have shown that vascular endothelial growth factor C (VEGFC) producing uNK cells induce transporter 1 (TAP-1) expression in endothelial cells [12]. Furthermore, the endometrium undergoes precisely defined morphological and biochemical changes during implantation and early 
TABLE 1: Composition of Zi Dan Yin (ZDY).

\begin{tabular}{lc}
\hline Components & Ratio \\
\hline (1) Sheng Di (Rehmannia glutinosa (Gaertn.) Libosch., root) & 15 \\
(2) Dan Shen (Salviae Miltiorrhizae Bge., root) & 10 \\
(3) Dang gui (Angelica sinensis (Oliv.) Diels., root) & 12 \\
(4) Chuan Duan (Dipsacus asperoides C. Y. Cheng et T.M. & 15 \\
Ai., root) & 12 \\
(5) Du Zhong (Eucommia ulmoides Oliv., cortex) & 15 \\
(6) Shan Yao (Dioscorea opposita Thunb., rhizome) & 6 \\
(7) Mei Gui-hua (Rosa rugosa Thunb., flower) & 6 \\
(8) Chuan Xiong (Ligusticum Chuanxiong Hort., rhizome) & 6 \\
(9) Yi Yi-ren (Coix lacryma-jobi L. var. ma-yuen (Roman.) & 12 \\
Stapf., seed) &
\end{tabular}

pregnancy; thus, there is no doubt that the preparation of epithelial cells is directed towards these process. We hypothesize that there similar paracrine communications occur between uNK cells and uterine epithelial cells. Our results revealed that soluble factors from uNK cells have substantial effects on endometrial epithelial gene expression. uNK cells were found to upregulate transcript levels in epithelial cells that are known to promote $\mathrm{uNK}$ cell proliferation, and these upregulated transcripts may contribute to the preparation for implantation and trophoblast migration and invasion.

In China, oriental herbal medicines have been used to treat infertility since ancient times [13]. Zi Dan Yin (ZDY), a compound of nine herbs (Table 1), was found to improve the morphology of the endometrium in mice [14]. Although the treatment effects of ZDY on mice have been confirmed, it is unclear whether ZDY contributes to the local immune responses. However, our results do not support the hypothesis that ZDY can improve the paracrine effects between uNK and endometrial epithelial cells.

\section{Materials and Methods}

2.1. Ethics Statement. All of the subjects understood and signed the informed consent form before participation. The experimental protocols were approved by the Ethics Committee of the Dongfang Hospital Human Ethics Committee (no. 2011090201).

2.2. Collection of Material. Decidual tissues were obtained from healthy women undergoing elective termination of a normal pregnancy between 7 and 8 weeks of gestation. The endometrial tissues were collected from endometrial biopsies taken during the proliferative phase of the cycle from women undergoing laparoscopy (Dongfang Hospital of Beijing University of Chinese Medicine, China) for benign disease. The average age was $30 \pm 1.3$ years, and the body mass index (BMI) was $22.1 \pm 0.8 \mathrm{~kg} / \mathrm{m}^{2}$. All of the nine women were Chinese of Han ethnicity. The exclusion criteria were hormonal stimulation, cancerous lesions, and irregular menstrual bleeding.
2.3. Isolation of the Uterine NK (uNK) Cells. The uNK cells were isolated as previously described $[15,16]$. Briefly, the decidual tissues were extensively washed with $\mathrm{Ca}^{2+}$ - and $\mathrm{Mg}^{+}{ }^{+}$-free Hank's balanced salt solution (HBSS) containing antibiotics, minced thoroughly between two scalpels into fragments of $1-2 \mathrm{~mm}^{3}$, and digested for $1 \mathrm{~h}$ at $37^{\circ} \mathrm{C}$ with gentle agitation in HBSS with $0.1 \%$ (w/v) collagenase I (Gibco, USA). The cell suspensions were layered over Ficoll-Hypaque medium (General Electric, USA) and centrifuged at $800 \times \mathrm{g}$ and room temperature for $25 \mathrm{~min}$. The cells at the interface were washed twice with Roswell Park Memorial Institute (RPMI)-1640 media with 10\% fetal calf serum (FCS) and antibiotics. After incubation for $20 \mathrm{~min}$ at $4^{\circ} \mathrm{C}$ with antiCD56 microbeads (Miltenyi Biotec, Ltd., Germany), the cells were washed with washing buffer (PBS, 2 mM EDTA, and $0.5 \%$ BSA $(\mathrm{w} / \mathrm{v}))$ and then loaded onto a MiniMACS Separator (MS) column in a MiniMACS magnet (Miltenyi Biotec, Ltd., Germany). After flushing the MS column three times, the $\mathrm{CD} 6^{+}$cells were flushed as indicated by the manufacturer. The purity of the uNK cells was $>90 \% \mathrm{CD}^{\circ} 6^{+} \mathrm{CD}^{-}$ according to the flow cytometric analysis. The uNK cells were cultured in RPMI 1640 media with 1\% FCS and IL-15 (10 ng/mL) (R\&D systems, USA), in which to maintain the viability of the purified uNK cells [17].

2.4. Production of uNK Cell-Secretion Medium. The uNK cellsecretion medium was prepared using $200 \mu \mathrm{L}$ of RPMI 1640 media with $1 \%$ FCS and IL-15 $(10 \mathrm{ng} / \mathrm{mL})$ containing $5 \times 10^{5}$ of the purified uNK cells. The cell suspension was placed in the upper chamber of a $0.4 \mu \mathrm{m}$ pore hanging cell culture insert (Millipore, USA) in a 24 -well tissue plate, and $1300 \mu \mathrm{L}$ of the same media without cells was placed in the lower chamber. As a result, only the soluble molecules from the uNK cells can pass through the filter into the lower chamber. The control medium was $1500 \mu \mathrm{L}$ of the RPMI 1640 media with $1 \%$ FCS and IL-15 $(10 \mathrm{ng} / \mathrm{mL})$, and this control medium was also used in the subsequent experiments. After incubation for $24 \mathrm{~h}$ at $37^{\circ} \mathrm{C}$, the uNK cell-secretion medium (in the lower chamber) and the control medium were collected and frozen at $-80^{\circ} \mathrm{C}$. The cells in the upper chamber were collected, and the cell viability was measured using a live/dead viability kit (Invitrogen, USA). Only the conditional medium from uNK populations with less than $35 \%$ dead cells after overnight incubation was used in the subsequent experiments.

2.5. Human Endometrial Epithelial Cell Culture. Human endometrial tissue was cut using scissors and dissociated into single-cell suspensions using $0.1 \%(\mathrm{w} / \mathrm{v})$ collagenase I for $50-$ $60 \mathrm{~min}$. Every $15 \mathrm{~min}$, the digests were pipetted, and their dissociation was monitored by microscopy. The cell suspensions were filtered using a 40-mesh screen to separate the single cells from undigested tissue. To remove the erythrocytes, the cells were resuspended in $4 \mathrm{~mL}$ of Dulbecco's modified Eagle's medium and Ham's nutrient F12 (DMEM/F12) with 1\% FCS, layered over Ficoll-Paque PLUS, and centrifuged for $25 \mathrm{~min}$ at $800 \times \mathrm{g}$. The leukocytes were removed with CD45-coated Dynabeads (Dynal Biotech, USA). The purified epithelial cell suspensions were then obtained through a further round of 
TABLE 2: Sequences of primers used in the quantitative real-time PCR analysis.

\begin{tabular}{lccc}
\hline Gene & \multicolumn{1}{c}{ Forward primer } & Reverse primer & Amplicon \\
\hline CXCL-10 & CTTTCTGACTCTAAGTGGCATTC & CACCCTTCTTTTTCATTGTAGCAA & $176 \mathrm{bp}$ \\
IL-15 & TGGCTGCTGGAAACCC & CACAAGTAGCACTGGATGGAAAT & $123 \mathrm{bp}$ \\
ICAM-1 & GAGGAAGGAGCAAGACTCAA & AGCATACCCAATAGGCAGCAAG & $141 \mathrm{bp}$ \\
NLRC-5 & AAACTTGATGACTCCTCCCTTACTT & TTAGACCTGGCTTTGTCCCTTAC & $120 \mathrm{bp}$ \\
IRF-1 & CCAGAAAAGCATAACACCAATCC & CCACTTTCCTTCACATTTCACTG & $144 \mathrm{bp}$ \\
GAPDH & GAGCCAAAAGGGTCATCATCT & AGGGGCCATCCACAGTCTTC & $231 \mathrm{bp}$ \\
\hline
\end{tabular}

magnetic bead sorting using Collection Epithelial Dynabeads (Dynal Biotech, USA). The epithelial cell preparations were $>95 \%$ pure.

The endometrial epithelial cells were cultured in serumfree bronchial epithelial growth medium (BEGM, Clonetics Crop) containing $2 \mathrm{~mL}$ of bovine pituitary extract (BPE), $0.5 \mathrm{~mL}$ of insulin, $0.5 \mathrm{~mL}$ of hydrocortisone (HC), $0.5 \mathrm{~mL}$ of gentamicin sulfate and amphotericin-B (GA-1000), $0.5 \mathrm{~mL}$ of retinoic acid, $0.5 \mathrm{~mL}$ of transferrin, $0.5 \mathrm{~mL}$ of triiodothyronine, $0.5 \mathrm{~mL}$ of epinephrine, and $0.5 \mathrm{~mL}$ of recombinant human epidermal growth factor (hEGF) (all supplied by Clonetics Corp., USA). The media was changed every five days. After two weeks, the epithelial cells were passed from six-well plates into $25 \mathrm{~cm}^{2}$ cell culture flasks.

2.6. ZDY Preparation. All of the crude drugs of ZDY were obtained from the Pharmacy Department of Dongfang Hospital of Beijing University of Chinese Medicine (Beijing Province, China). The quality of the raw herbs was controlled according to the requirement of the Pharmacopoeia of China. The aqueous extract of ZDY was prepared as follows. In brief, nine medicinal materials were mixed at the appropriate proportion, macerated for $1 \mathrm{~h}$ with eight volumes of distilled water and then decocted for $2 \mathrm{~h}$. The cooled extract was then filtered. This extraction procedure was repeated twice. The extracts were then combined and concentrated by boiling to a final volume of $100 \mathrm{~mL}(10.3 \mathrm{~g} / \mathrm{mL})$. The ZDY extract concentration of $2 \mathrm{mg} / \mathrm{mL}$ was further diluted with the epithelial cell culture medium and passed through $0.2 \mu \mathrm{m}$ sterilization filters for use in subsequent studies. The ZDY extract was stored at $2-8^{\circ} \mathrm{C}$ until further use. The concentration of ZDY was used according to previous analyses using a cell counting kit-8 (CCK-8).

\subsection{Treatment of Epithelial Cells with uNK Cell-Secretion} Medium. The endometrial epithelial cells were allocated into three groups: control, uNK, and ZDY groups. The cells in the control and UNK groups were treated with DMEM medium with $10 \%$ FBS for $24 \mathrm{~h}$, and the cells in the ZDY group were treated with $2 \mathrm{mg} / \mathrm{mL}$ ZDY for $24 \mathrm{~h}$. All of the cells were then washed twice with PBS and placed in serumfree DMEM for $24 \mathrm{~h}$ prior to the subsequent experiments. The uNK cell-secretion medium was pooled from different batches to decrease the variability. The DMEM in the ZDY and uNK groups was then replaced with $80 \%$ uNK cellsecretion medium and 20\% serum-free DMEM. The control group was treated with $80 \%$ control medium and $20 \%$ serumfree DMEM. After $6 \mathrm{~h}$ of incubation, the cells from the three groups were collected.

2.8. Microarray Experiments. The total RNA from endometrial epithelial cells from the control, uNK, and ZDY groups was extracted using Trizol (Invitrogen, USA). The RNA was purified using the RNeasy Mini Kit (Qiagen, Germany) according to the manufacturer's instructions, quantified by spectrophotometry. The microarray analysis was performed using the GeneChip 3' IVT Express Kit (Affymetrix). Briefly, the total RNA was subjected to reverse transcription, firststrand cDNA synthesis, double-strand DNA, in vitro transcription, and fragmentation. The samples were hybridized onto the GeneChip PrimeView Human Gene Expression Array (Affymetrix, USA), which covers more than 36,000 transcripts and variants. After $16 \mathrm{~h}$ of hybridization at $45^{\circ} \mathrm{C}$, the arrays were washed on a Fluidics Station 450 (Affymetrix, USA) and then scanned with a Scanner 3000 (Affymetrix, USA) to obtain the quantitative gene expression levels. The endometrial epithelial cells from the control, uNK, and ZDY groups were processed simultaneously throughout the experimental process, and three chips were used for each group.

2.9. Quantitative Real-Time PCR ( $q R T-P C R$ ) Analysis. To verify the results obtained from the microarray experiments, qRT-PCR verification was performed for five genes: chemokine (C-X-C motif) ligand 10 (CXCL-10), interleukin15 (IL-15), intercellular adhesion molecule 1 (ICAM-1), NLR family CARD domain containing 5 (NLRC-5), and interferon regulatory factor 1 (IRF-1). The cells from the control, uNK, and ZDY groups were washed twice with PBS, and the total RNA was then extracted using Trizol. The RNA was quantified by spectrophotometry. Reverse transcription was performed with $8 \mu \mathrm{L}$ of total RNA in a $20 \mu \mathrm{L}$ reaction volume using a standard cDNA Synthesis Kit (Takara BIO, Japan). The qRT-PCR primer sequences for the target genes were self-designed, and the PCR primers were ordered from Invitrogen. The primer sequences for target genes are shown in Table 2.

For each qRT-PCR reaction, the typical thermal cycling conditions included an initial activation step of $95^{\circ} \mathrm{C}$ for $5 \mathrm{~min}$ and 45 cycles of $95^{\circ} \mathrm{C}$ each for $30 \mathrm{sec}, 65^{\circ} \mathrm{C}$ for $35 \mathrm{sec}$, and $72^{\circ} \mathrm{C}$ for $5 \mathrm{~min}$. The PCR reactions were performed on an ABI Prism 7700 Sequence Detection System (Applied Biosystems, USA). For comparison of the target mRNA levels, 
TABLE 3: Transcripts that were altered by more than twofold in endometrial epithelial cells by stimulation with the uNK cell-secretion medium $(P<0.001)$. The transcript levels were obtained using a GeneChip PrimeView Human Gene Expression Array.

\begin{tabular}{|c|c|c|c|}
\hline Gene symbol & $\begin{array}{l}\text { Fold } \\
\text { change }\end{array}$ & $\begin{array}{l}\text { Gene } \\
\text { ID }\end{array}$ & Description \\
\hline \multicolumn{4}{|c|}{ Upregulated genes: 40 transcripts } \\
\hline \multicolumn{4}{|c|}{$\begin{array}{l}\text { Cytokines/membrane } \\
\text { proteins/immunological factors }\end{array}$} \\
\hline NLRC5 & 14.1 & 84166 & NLR family, CARD domain containing 5 \\
\hline IL15 & 5.8 & 3600 & Interleukin-15 \\
\hline IFIT3 & 5.8 & 3437 & Interferon-induced protein with tetratricopeptide repeats 3 \\
\hline CXCL10 & 3.1 & 3627 & Chemokine (C-X-C motif) ligand 10 \\
\hline IFIH1 & 2.9 & 64135 & Interferon induced with helicase $\mathrm{C}$ domain 1 \\
\hline IFIT5 & 2.8 & 24138 & Interferon-induced protein with tetratricopeptide repeats 5 \\
\hline IL-15RA & 2.7 & 3601 & Interleukin-15 receptor, alpha \\
\hline VEGFC & 2.5 & 7424 & Vascular endothelial growth factor $\mathrm{C}$ \\
\hline PDCD1LG2 & 2.5 & 80380 & Programmed cell death 1 ligand 2 \\
\hline \multicolumn{4}{|l|}{ Transporters } \\
\hline TAP1 & 3.4 & 6890 & Transporter 1, ATP-binding cassette, sub-family B (MDR/TAP) \\
\hline TAP2 & 2.6 & 6891 & $\begin{array}{l}\text { Transporter 2, ATP-binding cassette, sub-family B } \\
\text { (MDR/TAP) }\end{array}$ \\
\hline APOL3 & 2.1 & 80833 & Apolipoprotein L, 3 \\
\hline VLDLR & 2.1 & 7436 & Very low density lipoprotein receptor \\
\hline APOL2 & 2.1 & 23780 & Apolipoprotein L, 2 \\
\hline \multicolumn{4}{|c|}{ Structural factors } \\
\hline LMNB1 & 4.3 & 4001 & Lamin B1 \\
\hline \multicolumn{4}{|l|}{ Transcription } \\
\hline IRF1 & 11 & 3659 & Interferon regulatory factor 1 \\
\hline IRF9 & 4.9 & 10379 & Interferon regulatory factor 9 \\
\hline STAT1 & 4.5 & 6772 & Signal transducer and activator of transcription $1,91 \mathrm{kda}$ \\
\hline TAF15 & 2.1 & 8148 & $\begin{array}{l}\text { TAF15 RNA polymerase II, TATA box binding protein } \\
\text { (TBP)-associated factor, } 68 \mathrm{kda}\end{array}$ \\
\hline \multicolumn{4}{|c|}{ Cell-cell adhesion } \\
\hline ICAM1 & 5.1 & 3383 & Intercellular adhesion molecule 1 \\
\hline \multicolumn{4}{|l|}{ Ion binding } \\
\hline $\mathrm{C} 1 \mathrm{~S}$ & 3.2 & 716 & Complement component 1 , s subcomponent \\
\hline SP110 & 2.9 & 3431 & SP110 nuclear body protein \\
\hline PARP12 & 2.3 & 64761 & Poly (ADP-ribose) polymerase family, member 12 \\
\hline ZC3HAV1 & 2.3 & 56829 & Zinc finger CCCH-type, antiviral 1 \\
\hline \multicolumn{4}{|c|}{ Tryptophan metabolism } \\
\hline IDO1 & 6.2 & 3620 & Indoleamine 2,3-dioxygenase 1 \\
\hline WARS & 4.2 & 7453 & Tryptophanyl-trna synthetase \\
\hline \multicolumn{4}{|l|}{ Enzyme activity } \\
\hline DTX3L & 4.6 & 151636 & Deltex 3-like (Drosophila) \\
\hline PSMB9 & 3.3 & 5698 & $\begin{array}{l}\text { Proteasome (prosome, macropain) subunit, beta type, } 9 \text { (large } \\
\text { multifunctional peptidase 2) }\end{array}$ \\
\hline MSRB1 & 2.5 & 51734 & Methionine sulfoxide reductase B1 \\
\hline CTSZ & 2.2 & 1522 & Cathepsin Z \\
\hline \multicolumn{4}{|c|}{ Nucleotide metabolism } \\
\hline GBP5 & 10.5 & 115362 & Guanylate binding protein 5 \\
\hline GBP1 & 5.8 & 2633 & Guanylate binding protein 1 , interferon-inducible \\
\hline PARP14 & 5.2 & 54625 & Poly (ADP-ribose) polymerase family, member 14 \\
\hline GBP2 & 3.2 & 2634 & Guanylate binding protein 2, interferon-inducible \\
\hline
\end{tabular}


TABle 3: Continued.

\begin{tabular}{|c|c|c|c|}
\hline Gene symbol & $\begin{array}{c}\text { Fold } \\
\text { change }\end{array}$ & $\begin{array}{l}\text { Gene } \\
\text { ID }\end{array}$ & Description \\
\hline MX1 & 2.5 & 4599 & $\begin{array}{l}\text { Myxovirus (influenza virus) resistance 1, interferon-inducible } \\
\text { protein p78 (mouse) }\end{array}$ \\
\hline RAD23B & 2.3 & 5887 & RAD23 homolog B (S. Cerevisiae) \\
\hline GBP7 & 2 & 388646 & Guanylate binding protein 7 \\
\hline \multicolumn{4}{|l|}{ Others } \\
\hline FAM117B & 3.6 & 150864 & Family with sequence similarity 117 , member B \\
\hline C19orf66 & 2.6 & 55337 & Chromosome 19 open reading frame 66 \\
\hline NUB1 & 2.5 & 51667 & Negative regulator of ubiquitin-like proteins 1 \\
\hline \multicolumn{4}{|c|}{ Downregulated genes: 129 transcripts } \\
\hline \multicolumn{4}{|c|}{$\begin{array}{l}\text { Cytokines/membrane } \\
\text { proteins/immunological factors }\end{array}$} \\
\hline IL36G & -3.4 & 56300 & Interleukin-36, gamma \\
\hline IL33 & -3.0 & 90865 & Interleukin-33 \\
\hline IL1RN & -2.5 & 3557 & Interleukin-1 receptor antagonist \\
\hline DNAJB14 & -2.5 & 79982 & Dnaj (Hsp40) homolog, subfamily B, member 14 \\
\hline KITLG & -2.3 & 4254 & KIT ligand \\
\hline LARP4 & -2.3 & 113251 & La ribonucleoprotein domain family, member 4 \\
\hline CLDN4 & -2.2 & 1364 & Claudin 4 \\
\hline CUL5 & -2.2 & 8065 & Cullin 5 \\
\hline \multicolumn{4}{|c|}{ Intracellular/signalling factors } \\
\hline ITGB8 & -3.5 & 3696 & Integrin, beta 8 \\
\hline RICTOR & -2.8 & 253260 & RPTOR independent companion of MTOR, complex 2 \\
\hline IL6ST & -2.6 & 3572 & Interleukin-6 signal transducer (gp130, oncostatin M receptor) \\
\hline SOCS4 & -2.5 & 122809 & Suppressor of cytokine signaling 4 \\
\hline NRIP1 & -2.5 & 8204 & Nuclear receptor interacting protein 1 \\
\hline SEMA3A & -2.5 & 10371 & $\begin{array}{l}\text { Sema domain, immunoglobulin domain (Ig), short basic } \\
\text { domain, secreted, (semaphorin) 3A }\end{array}$ \\
\hline PLCB4 & -2.2 & 5332 & Phospholipase C, beta 4 \\
\hline COPS2 & -2.2 & 9318 & $\begin{array}{l}\text { COP9 constitutive photomorphogenic homolog subunit } 2 \\
\text { (Arabidopsis) }\end{array}$ \\
\hline BMPR2 & -2 & 659 & $\begin{array}{l}\text { Bone morphogenetic protein receptor, type II } \\
\text { (serine/threonine kinase) }\end{array}$ \\
\hline \multicolumn{4}{|l|}{ Transporters } \\
\hline TPR & -3.4 & 7175 & Translocated promoter region, nuclear basket protein \\
\hline KIAA1033 & -2.5 & 23325 & Kiaa1033 \\
\hline $\mathrm{BAZ2B}$ & -2.5 & 29994 & Bromodomain adjacent to zinc finger domain, 2B \\
\hline TMED5 & -2.2 & 50999 & Transmembrane emp24 protein transport domain containing 5 \\
\hline SLC4A7 & -2 & 9497 & $\begin{array}{l}\text { Solute carrier family } 4 \text {, sodium bicarbonate cotransporter, } \\
\text { member } 7\end{array}$ \\
\hline \multicolumn{4}{|c|}{ Structural factors } \\
\hline ROCK2 & -2.9 & 9475 & Rho-associated, coiled-coil containing protein kinase 2 \\
\hline \multicolumn{4}{|l|}{ Transcription } \\
\hline $\mathrm{BDP} 1$ & -3.6 & 55814 & $\begin{array}{l}\text { B double prime 1, subunit of RNA polymerase III transcription } \\
\text { initiation factor IIIB }\end{array}$ \\
\hline TRIP11 & -3.4 & 9321 & Thyroid hormone receptor interactor 11 \\
\hline ZNF644 & -3.3 & 84146 & Zinc finger protein 644 \\
\hline CHD9 & -3.2 & 80205 & Chromodomain helicase DNA binding protein 9 \\
\hline ZNF480 & -3.1 & 147657 & Zinc finger protein 480 \\
\hline
\end{tabular}


TABle 3: Continued.

\begin{tabular}{|c|c|c|c|}
\hline Gene symbol & $\begin{array}{c}\text { Fold } \\
\text { change }\end{array}$ & $\begin{array}{l}\text { Gene } \\
\text { ID }\end{array}$ & Description \\
\hline ZNF292 & -3 & 23036 & Zinc finger protein 292 \\
\hline ZNF148 & -2.8 & 7707 & Zinc finger protein 148 \\
\hline ZNF267 & -2.8 & 10308 & Zinc finger protein 267 \\
\hline ZBTB20 & -2.7 & 26137 & Zinc finger and BTB domain containing 20 \\
\hline CREB1 & -2.7 & 1385 & Camp responsive element binding protein 1 \\
\hline ZNF638 & -2.6 & 27332 & Zinc finger protein 638 \\
\hline ZNF518A & -2.6 & 9849 & Zinc finger protein $518 \mathrm{~A}$ \\
\hline ESF1 & -2.6 & 51575 & $\begin{array}{l}\text { ESF1, nucleolar pre-rrna processing protein, homolog (S. } \\
\text { Cerevisiae) }\end{array}$ \\
\hline FAR1 & -2.6 & 84188 & Fatty acyl coa reductase 1 \\
\hline ZNF91 & -2.5 & 7644 & Zinc finger protein 91 \\
\hline CENPF & -2.5 & 1063 & Centromere protein F, 350/400 kda (mitosin) \\
\hline FOXN2 & -2.4 & 3344 & Forkhead box N2 \\
\hline DNTTIP2 & -2.2 & 30836 & Deoxynucleotidyl transferase, terminal, interacting protein 2 \\
\hline TMF1 & -2.2 & 7110 & TATA element modulatory factor 1 \\
\hline BCLAF1 & -2.2 & 9774 & BCL2-associated transcription factor 1 \\
\hline CEBPZ & -2.2 & 10153 & CCAAT/enhancer binding protein (C/EBP), zeta \\
\hline ZNF146 & -2.1 & 7705 & Zinc finger protein 146 \\
\hline HIF1A & -2 & 3091 & $\begin{array}{l}\text { Hypoxia inducible factor 1, alpha subunit (basic } \\
\text { helix-loop-helix transcription factor) }\end{array}$ \\
\hline \multicolumn{4}{|c|}{ Cell-cell adhesion } \\
\hline DST & -2.9 & 667 & Dystonin \\
\hline \multicolumn{4}{|l|}{ Ion binding } \\
\hline ATRX & -4.6 & 546 & Alpha thalassemia/mental retardation syndrome X-linked \\
\hline EEA1 & -3.4 & 8411 & Early endosome antigen 1 \\
\hline RSF1 & -2.6 & 51773 & Remodeling and spacing factor 1 \\
\hline NIN & -2.6 & 51199 & Ninein (GSK3B interacting protein) \\
\hline SCAF11 & -2.5 & 9169 & SR-related CTD-associated factor 11 \\
\hline MIB1 & -2 & 57534 & Mind bomb E3 ubiquitin protein ligase 1 \\
\hline TRMT13 & -2 & 54482 & Trna methyltransferase 13 homolog (S. Cerevisiae) \\
\hline \multicolumn{4}{|l|}{ Kinase } \\
\hline CCDC88A & -3.1 & 55704 & Coiled-coil domain containing 88A \\
\hline FER & -3.1 & 2241 & Fer (fps/fes related) tyrosine kinase \\
\hline KTN1 & -3 & 3895 & Kinectin 1 (kinesin receptor) \\
\hline SCYL2 & -2.6 & 55681 & SCY1-like 2 (S. Cerevisiae) \\
\hline AKAP11 & -2.5 & 11215 & A kinase (PRKA) anchor protein 11 \\
\hline PIK3C2A & -2.5 & 5286 & $\begin{array}{l}\text { Phosphatidylinositol-4-phosphate 3-kinase, catalytic subunit } \\
\text { type } 2 \text { alpha }\end{array}$ \\
\hline CDK6 & -2.3 & 1021 & Cyclin-dependent kinase 6 \\
\hline NEK1 & -2.3 & 4750 & NIMA (never in mitosis gene a)-related kinase 1 \\
\hline SLK & -2.2 & 9748 & STE20-like kinase \\
\hline UTRN & -2.2 & 7402 & Utrophin \\
\hline $\mathrm{RB} 1 \mathrm{CC} 1$ & -2 & 9821 & RB1-inducible coiled-coil 1 \\
\hline YES1 & -2 & 7525 & V-yes-1 Yamaguchi sarcoma viral oncogene homolog 1 \\
\hline \multicolumn{4}{|c|}{ Enzyme activity } \\
\hline RANBP2 & -2.9 & 5903 & RAN binding protein 2 \\
\hline JMJD1C & -2.7 & 221037 & Jumonji domain containing $1 \mathrm{C}$ \\
\hline
\end{tabular}


TABLe 3: Continued.

\begin{tabular}{|c|c|c|c|}
\hline Gene symbol & $\begin{array}{l}\text { Fold } \\
\text { change }\end{array}$ & $\begin{array}{l}\text { Gene } \\
\text { ID }\end{array}$ & Description \\
\hline RNF6 & -2.7 & 6049 & Ring finger protein ( $\mathrm{C} 3 \mathrm{H} 2 \mathrm{C} 3$ type $) 6$ \\
\hline LTN1 & -2.6 & 26046 & Listerin E3 ubiquitin protein ligase 1 \\
\hline RBBP6 & -2.5 & 5930 & Retinoblastoma binding protein 6 \\
\hline PPIG & -2.5 & 9360 & Peptidylprolyl isomerase G (cyclophilin G) \\
\hline PTAR1 & -2.4 & 375743 & Protein prenyltransferase alpha subunit repeat containing 1 \\
\hline PYROXD1 & -2.3 & 79912 & Pyridine nucleotide-disulphide oxidoreductase domain 1 \\
\hline LIG4 & -2.3 & 3981 & Ligase IV, DNA, ATP-dependent \\
\hline RAD50 & -2.1 & 10111 & RAD50 homolog (S. Cerevisiae) \\
\hline DBF4 & -2 & 10926 & DBF4 homolog (S. Cerevisiae) \\
\hline \multicolumn{4}{|c|}{ Nucleotide metabolism } \\
\hline CHD1 & -2.6 & 1105 & Chromodomain helicase DNA binding protein 1 \\
\hline CHML & -2.5 & 1122 & Choroideremia-like (Rab escort protein 2) \\
\hline ELMOD2 & -2.1 & 255520 & ELMO/CED-12 domain containing 2 \\
\hline NAA15 & -2 & 80155 & $\mathrm{~N}$ (alpha)-acetyltransferase 15 , nata auxiliary subunit \\
\hline KIF20B & -2 & 9585 & Kinesin family member 20B \\
\hline \multicolumn{4}{|l|}{ Others } \\
\hline GOLGA4 & -3.9 & 2803 & Golgin A4 \\
\hline ASPM & -3.4 & 259266 & $\begin{array}{l}\text { Asp (abnormal spindle) homolog, microcephaly associated } \\
\text { (Drosophila) }\end{array}$ \\
\hline CEP350 & -3.3 & 9857 & Centrosomal protein $350 \mathrm{kda}$ \\
\hline C10orf118 & -3.2 & 55088 & Chromosome 10 open reading frame 118 \\
\hline GALNT5 & -3.2 & 11227 & $\begin{array}{l}\text { UDP-N-acetyl-alpha-D-galactosamine:polypeptide } \\
\text { N-acetylgalactosaminyltransferase } 5 \text { (galnac-T5) }\end{array}$ \\
\hline BOD1L1 & -3.1 & 259282 & Biorientation of chromosomes in cell division 1-like 1 \\
\hline ANKRD12 & -3.1 & 23253 & Ankyrin repeat domain 12 \\
\hline RIF1 & -3 & 55183 & RAP1 interacting factor homolog (yeast) \\
\hline KIAA2026 & -3 & 158358 & Kiaa2026 \\
\hline FAM111B & -2.9 & 374393 & Family with sequence similarity 111, member B \\
\hline EIF5B & -2.8 & 9669 & Eukaryotic translation initiation factor 5B \\
\hline OSBPL8 & -2.8 & 114882 & Oxysterol binding protein-like 8 \\
\hline GOLGB1 & -2.8 & 2804 & Golgin B1 \\
\hline MALAT1 & -2.7 & 378938 & $\begin{array}{l}\text { Metastasis associated lung adenocarcinoma transcript } 1 \\
\text { (non-protein coding) }\end{array}$ \\
\hline PRPF40A & -2.7 & 55660 & $\begin{array}{l}\text { PRP } 40 \text { pre-mrna processing factor } 40 \text { homolog A (S. } \\
\text { Cerevisiae) }\end{array}$ \\
\hline QSER1 & -2.6 & 79832 & Glutamine and serine rich 1 \\
\hline THOC2 & -2.6 & 57187 & THO complex 2 \\
\hline RASSF6 & -2.6 & 166824 & Ras association (ralgds/AF-6) domain family member 6 \\
\hline STAG2 & -2.6 & 10735 & Stromal antigen 2 \\
\hline NUFIP2 & -2.5 & 57532 & $\begin{array}{l}\text { Nuclear fragile X mental retardation protein interacting } \\
\text { protein } 2\end{array}$ \\
\hline SMC2 & -2.5 & 10592 & Structural maintenance of chromosomes 2 \\
\hline SLC30A1 & -2.5 & 7779 & Solute carrier family 30 (zinc transporter), member 1 \\
\hline ZNF268 & -2.4 & 10795 & Zinc finger protein 268 \\
\hline KIAA1109 & -2.4 & 84162 & Kiaal109 \\
\hline NIPBL & -2.4 & 25836 & Nipped-B homolog (Drosophila) \\
\hline ANKRD30BP2 & -2.4 & 149992 & Ankyrin repeat domain $30 \mathrm{~B}$ pseudogene 2 \\
\hline KIF5B & -2.4 & 3799 & Kinesin family member 5B \\
\hline
\end{tabular}


TABLe 3: Continued.

\begin{tabular}{|c|c|c|c|}
\hline Gene symbol & $\begin{array}{c}\text { Fold } \\
\text { change }\end{array}$ & $\begin{array}{l}\text { Gene } \\
\text { ID }\end{array}$ & Description \\
\hline SMC4 & -2.3 & 10051 & Structural maintenance of chromosomes 4 \\
\hline SMC5 & -2.3 & 23137 & Structural maintenance of chromosomes 5 \\
\hline NEMF & -2.3 & 9147 & Nuclear export mediator factor \\
\hline GCC2 & -2.3 & 9648 & GRIP and coiled-coil domain containing 2 \\
\hline EXOC5 & -2.3 & 10640 & Exocyst complex component 5 \\
\hline $\mathrm{FCHO} 2$ & -2.3 & 115548 & FCH domain only 2 \\
\hline SMC6 & -2.3 & 79677 & Structural maintenance of chromosomes 6 \\
\hline HOOK3 & -2.2 & 84376 & Hook homolog 3 (Drosophila) \\
\hline LGALSL & -2.1 & 29094 & Lectin, galactoside-binding-like \\
\hline SEMA3C & -2.1 & 10512 & $\begin{array}{l}\text { Sema domain, immunoglobulin domain (Ig), short basic } \\
\text { domain, secreted, (semaphorin) 3C }\end{array}$ \\
\hline TMEM106B & -2.1 & 54664 & Transmembrane protein $106 \mathrm{~B}$ \\
\hline PCM1 & -2.1 & 5108 & Pericentriolar material 1 \\
\hline KRTAP2-3 & -2.1 & 730755 & Keratin associated protein $2-3$ \\
\hline MACC1 & -2.1 & 346389 & Metastasis associated in colon cancer 1 \\
\hline CCDC82 & -2.1 & 79780 & Coiled-coil domain containing 82 \\
\hline TTC37 & -2.1 & 9652 & Tetratricopeptide repeat domain 37 \\
\hline UACA & -2.1 & 55075 & $\begin{array}{l}\text { Uveal autoantigen with coiled-coil domains and ankyrin } \\
\text { repeats }\end{array}$ \\
\hline CEP290 & -2 & 80184 & Centrosomal protein $290 \mathrm{kda}$ \\
\hline USP53 & -2 & 54532 & Ubiquitin specific peptidase 53 \\
\hline METRNL & -2 & 284207 & Meteorin, glial cell differentiation regulator-like \\
\hline
\end{tabular}

the cDNA concentration was normalized with that of the glyceraldehyde-3-phosphate dehydrogenase (GAPDH) PCR product. The target mRNA expression was analyzed using the 2- $\Delta \Delta \mathrm{Ct}$ algorithm.

2.10. Western Blot Analysis of ICAM-1. The cells from the control, uNK, and ZDY groups were lysed with RIPA lysis buffer (Applygen, China) supplemented with a protease inhibitor cocktail (Applygen, China). The protein concentrations were quantified using bicinchoninic acid (BCA; Applygen, China). The proteins were separated using 10\% sodium dodecyl sulfate-polyacrylamide gel electrophoresis (SDS-PAGE) and transferred to nitrocellulose. The blots were blocked overnight in Tris-buffered-saline with Tween (TBST) containing 5\% dried milk, washed three times for $5 \mathrm{~min}$ each in TBST, and then incubated overnight in a rocker at $4^{\circ} \mathrm{C}$ with a cocktail containing ICAM-1 (Abcam, UK; at a dilution of $1: 1000)$ and $2 \%$ dried milk in TBST. The blots were then washed three times for $10 \mathrm{~min}$ each in TBST and incubated with the secondary antibody (Applygen, China; at a dilution of $1: 10000)$ for $1 \mathrm{~h}$ at room temperature in a rocker. The blots were washed three times for $10 \mathrm{~min}$ each in TBST and then visualized with the Super ECL Plus Detection Reagent (Applygen, China). The ECL signals were detected with the Quantity One software (Bio-Rad, USA). GAPDH (Abcam,
UK) was used as the internal control to validate the amount of protein.

2.11. Statistical Analysis. All of the variables were tested in three different culture experiments. The data were analyzed by ANOVA. In the microarray experiments, the significance level was determined by ANOVA with Benjamini-Hochberg correction $(P<0.001)$. We selected the up- and downregulated genes that showed a median fold change greater than 2 and a $P<0.001$. The data from the qRT-PCR and western blot analyses are presented as means \pm SEM after normalization with the average value of the housekeeping gene obtained for each group, and the significance level was $P<0.01$. The graphs of the data were produced using the Microsoft Excel software.

\section{Results}

3.1. Microarray Experiments. Gene expression profiling using a microarray was used to compare the transcript expression levels in epithelial cells treated with control medium, uNK cell-secretion medium, and ZDY + uNK cell-secretion medium.

This analysis identified 169 transcripts that exhibited a statistically significant change in their median expression level (either upregulated or downregulated) in response to 
TABLE 4: Transcripts that were altered by more than twofold in endometrial epithelial cells by stimulation with ZDY and uNK cell-secretion medium $(P<0.001)$. The transcript levels were obtained using a GeneChip PrimeView Human Gene Expression Array.

\begin{tabular}{|c|c|c|c|}
\hline Gene symbol & $\begin{array}{l}\text { Fold } \\
\text { change }\end{array}$ & Gene ID & Description \\
\hline \multicolumn{4}{|c|}{ Upregulated genes: 18 transcripts } \\
\hline \multicolumn{4}{|c|}{ Intracellular/signalling factors } \\
\hline AKR1C2 & 2.7 & 1646 & $\begin{array}{l}\text { Aldo-keto reductase family 1, member C2 (dihydrodiol } \\
\text { dehydrogenase } 2 \text {; bile acid binding protein; } 3 \text {-alpha } \\
\text { hydroxysteroid dehydrogenase, type III) }\end{array}$ \\
\hline \multicolumn{4}{|c|}{ Structural factors } \\
\hline TLN1 & 2.7 & 7094 & Talin 1 \\
\hline KRT75 & 2.0 & 9119 & Keratin 75 \\
\hline \multicolumn{4}{|l|}{ Transcription } \\
\hline NUPR1 & 2.6 & 26471 & Nuclear protein, transcriptional regulator, 1 \\
\hline \multicolumn{4}{|l|}{ Ion binding } \\
\hline S100A8 & 2.1 & 6279 & S100 calcium binding protein $\mathrm{A} 8$ \\
\hline \multicolumn{4}{|c|}{ Enzyme activity } \\
\hline ASNS & 5.2 & 440 & Asparagine synthetase (glutamine-hydrolyzing) \\
\hline AKR1C1 & 3.3 & 1645 & $\begin{array}{l}\text { Aldo-keto reductase family } 1 \text {, member } \mathrm{C} 1 \text { (dihydrodiol } \\
\text { dehydrogenase 1; } 20 \text {-alpha (3-alpha)-hydroxysteroid } \\
\text { dehydrogenase) }\end{array}$ \\
\hline NQO1 & 2.9 & 1728 & $\mathrm{NAD}(\mathrm{P}) \mathrm{H}$ dehydrogenase, quinone 1 \\
\hline CBS & 2.5 & 875 & Cystathionine-beta-synthase \\
\hline AKR1C3 & 2.3 & 8644 & $\begin{array}{l}\text { Aldo-keto reductase family 1, member C3 (3-alpha } \\
\text { hydroxysteroid dehydrogenase, type II) }\end{array}$ \\
\hline PSAT1 & 2.2 & 29968 & Phosphoserine aminotransferase 1 \\
\hline HMOX1 & 2.2 & 3162 & Heme oxygenase (decycling) 1 \\
\hline GPX2 & 2.2 & 2877 & Glutathione peroxidase 2 (gastrointestinal) \\
\hline DHRS3 & 2.1 & 9249 & Dehydrogenase/reductase (SDR family) member 3 \\
\hline H1FX & 2.1 & 8971 & H1 histone family, member X \\
\hline \multicolumn{4}{|l|}{ Others } \\
\hline SLC7A11 & 3.1 & 23657 & $\begin{array}{l}\text { Solute carrier family } 7 \text { (anionic amino acid transporter light } \\
\text { chain, xc-system), member } 11\end{array}$ \\
\hline $\mathrm{CTH}$ & 2.4 & 1491 & Cystathionase (cystathionine gamma-lyase) \\
\hline HSPB8 & 2.2 & 26353 & Heat shock $22 \mathrm{kda}$ protein 8 \\
\hline \multicolumn{4}{|c|}{ Downregulated genes: 33 transcripts } \\
\hline \multicolumn{4}{|c|}{$\begin{array}{l}\text { Cytokines/membrane } \\
\text { proteins/signalling factors }\end{array}$} \\
\hline CXCL3 & -2.1 & 2921 & Chemokine (C-X-C motif) ligand 3 \\
\hline CAPRIN2 & -2.0 & 65981 & Caprin family member 2 \\
\hline \multicolumn{4}{|l|}{ Transporters } \\
\hline COG5 & -2.0 & 10466 & Component of oligomeric golgi complex 5 \\
\hline \multicolumn{4}{|c|}{ Structural factors } \\
\hline LMNB1 & -5.5 & 4001 & Lamin B1 \\
\hline PNN & -2.9 & 5411 & Pinin, desmosome associated protein \\
\hline MFAP5 & -2.2 & 8076 & Microfibrillar associated protein 5 \\
\hline RPL37A & -2.2 & 6168 & Ribosomal protein $137 \mathrm{a}$ \\
\hline \multicolumn{4}{|l|}{ Transcription } \\
\hline HIRA & -3.6 & 7290 & $\begin{array}{l}\text { HIR histone cell cycle regulation defective homolog A (S. } \\
\text { Cerevisiae) }\end{array}$ \\
\hline YAP1 & -2.4 & 10413 & Yes-associated protein 1 \\
\hline ZNF226 & -2.4 & 7769 & Zinc finger protein 226 \\
\hline
\end{tabular}


TABLE 4: Continued.

\begin{tabular}{|c|c|c|c|}
\hline Gene symbol & $\begin{array}{l}\text { Fold } \\
\text { change }\end{array}$ & Gene ID & Description \\
\hline TAF15 & -2.1 & 8148 & $\begin{array}{l}\text { TAF15 RNA polymerase II, TATA box binding protein } \\
\text { (TBP)-associated factor, } 68 \mathrm{kda}\end{array}$ \\
\hline NFKBIZ & -2.1 & 64332 & $\begin{array}{l}\text { Nuclear factor of kappa light polypeptide gene enhancer in } \\
\text { B-cells inhibitor, zeta }\end{array}$ \\
\hline \multicolumn{4}{|l|}{ Ion binding } \\
\hline ZDHHC11 & -2.2 & 79844 & Zinc finger, DHHC-type containing 11 \\
\hline RNF145 & -2.1 & 153830 & Ring finger protein 145 \\
\hline \multicolumn{4}{|l|}{ Kinase } \\
\hline AHSA2 & -2.0 & 130872 & $\begin{array}{l}\text { AHA1, activator of heat shock } 90 \text { kda protein atpase homolog } 2 \\
\text { (yeast) }\end{array}$ \\
\hline \multicolumn{4}{|l|}{ Enzyme activity } \\
\hline TNKS2 & -7.7 & 80351 & $\begin{array}{l}\text { Tankyrase, TRF1-interacting ankyrin-related ADP-ribose } \\
\text { polymerase } 2\end{array}$ \\
\hline \multicolumn{4}{|c|}{ Nucleotide metabolism } \\
\hline RAD23B & -2.0 & 5887 & RAD23 homolog B (S. Cerevisiae) \\
\hline $\mathrm{RCC1}$ & -2.0 & 1104 & Regulator of chromosome condensation 1 \\
\hline \multicolumn{4}{|l|}{ Others } \\
\hline GOLGA8A & -5.4 & 23015 & Golgin A8 family, member A \\
\hline LUC7L3 & -3.8 & 51747 & LUC7-like 3 (S. Cerevisiae) \\
\hline HNRNPA2B1 & -2.9 & 3181 & Heterogeneous nuclear ribonucleoprotein A2/B1 \\
\hline XIST & -2.8 & 7503 & $\mathrm{X}$ (inactive)-specific transcript (non-protein coding) \\
\hline SNORA33 & -2.6 & 594839 & Small nucleolar RNA, H/ACA box 33 \\
\hline SNHG12 & -2.5 & 85028 & Small nucleolar RNA host gene 12 (non-protein coding) \\
\hline C20orf197 & -2.4 & 284756 & Chromosome 20 open reading frame 197 \\
\hline EML2 & -2.4 & 24139 & Echinoderm microtubule associated protein like 2 \\
\hline PNISR & -2.3 & 25957 & PNN-interacting serine/arginine-rich protein \\
\hline KIAA0020 & -2.3 & 9933 & Kiaa0020 \\
\hline HMMR & -2.2 & 3161 & Hyaluronan-mediated motility receptor (RHAMM) \\
\hline NOP58 & -2.2 & 51602 & NOP58 ribonucleoprotein homolog (yeast) \\
\hline PILRB & -2 & 29990 & Paired immunoglobin-like type 2 receptor beta \\
\hline NCAPG & -2 & 64151 & Non-SMC condensin I complex, subunit G \\
\hline PICALM & -2 & 8301 & Phosphatidylinositol binding clathrin assembly protein \\
\hline
\end{tabular}

uNK cell-secretion medium compared with their control level. These transcripts are listed in Table 3. A total of 40 genes were found upregulated, and 129 genes were downregulated. The largest group of upregulated genes included immunomodulatory gene regulators, cytokines, such as interleukin-15 (IL-15), chemokine (C-X-C motif) ligand 10 (CXCL-10), and vascular endothelial growth factor C (VEGF$\mathrm{C})$, and cytokine receptors, such as interleukin-15 receptor alpha (IL-15RA). Additionally, the upregulated transcripts encode proteins associated with transport, structuration, and transcription. The level of adhesion molecule intercellular adhesion molecule 1 (ICAM-1) was also altered. ICAM-1 binds to the leucocyte integrins LFA-1 and Mac-1 $[18,19]$, which are expressed on uNK cells. Thus, this change in the level of ICAM-1 should increase the localized interactions between uNK cells and epithelial cells. A number of transcripts regulating enzyme activity, such as the deltex 3-like (Drosophila) (DYX3L) and the proteasome (prosome, macropain) subunit beta type 9 (large multifunctional peptidase 2) (PSMB9), and several transcripts regulating nucleotide metabolism genes, such as guanylate binding protein 5 (GBP5) and guanylate binding protein 1 interferoninducible (GBP1), were also upregulated. In addition, genes with various functions, such as the icon binding complement component $1 \mathrm{~S}$ subcomponent (C1S), SP110 nuclear body protein (SP110), tryptophan metabolism indoleamine 2,3dioxygenase 1 (IDO1), and tryptophanyl-tRNA synthetase (WARS), and several genes with unknown function were found to be upregulated. The largest group of downregulated genes encodes transcription factors, such as B double prime 1 subunit of RNA polymerase III transcription initiation factor IIIB (BDP1) and thyroid hormone receptor interactor 11 (TRIP11). The levels of immunomodulatory gene regulators, including interleukin-36 gamma (IL-36G) and interleukin-33 


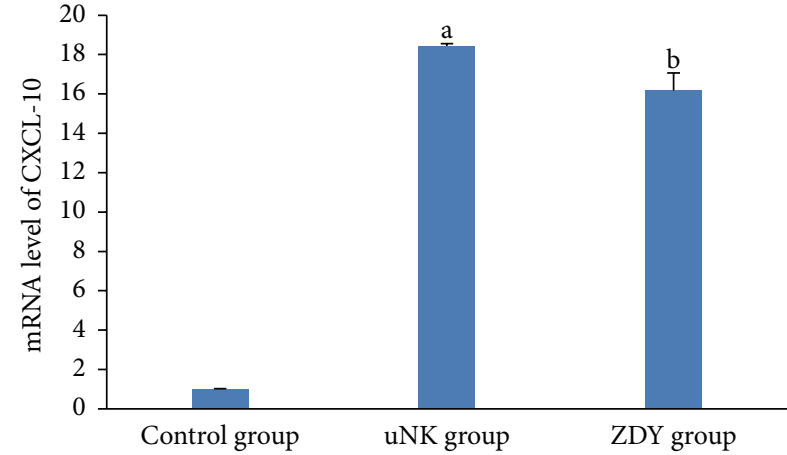

(a)

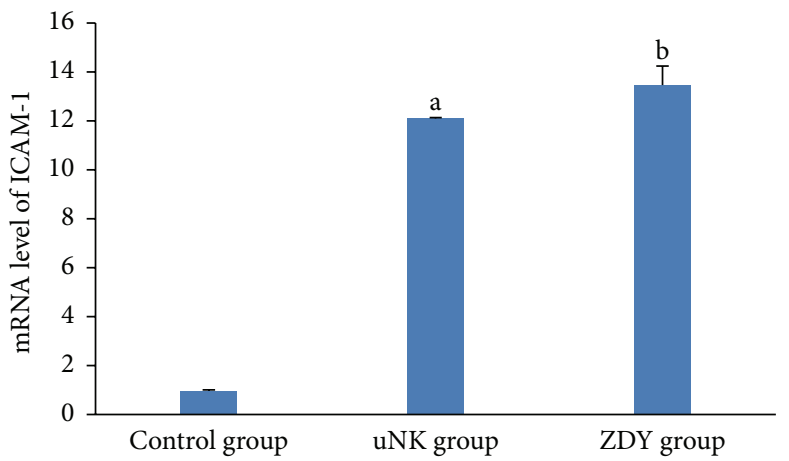

(c)

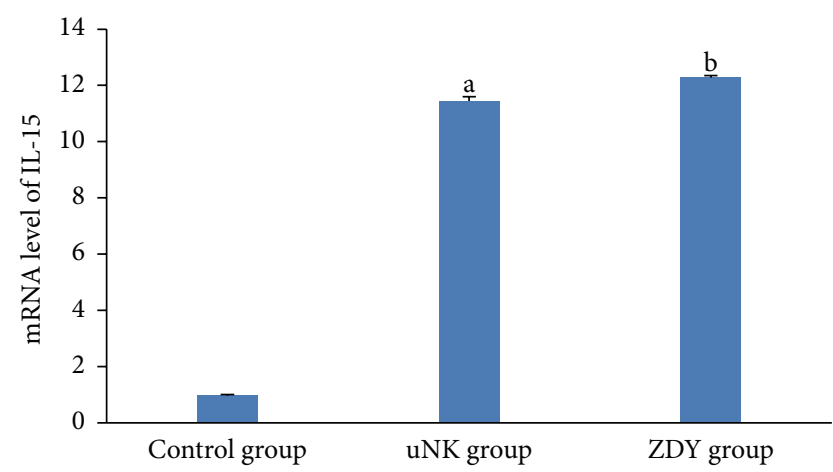

(b)

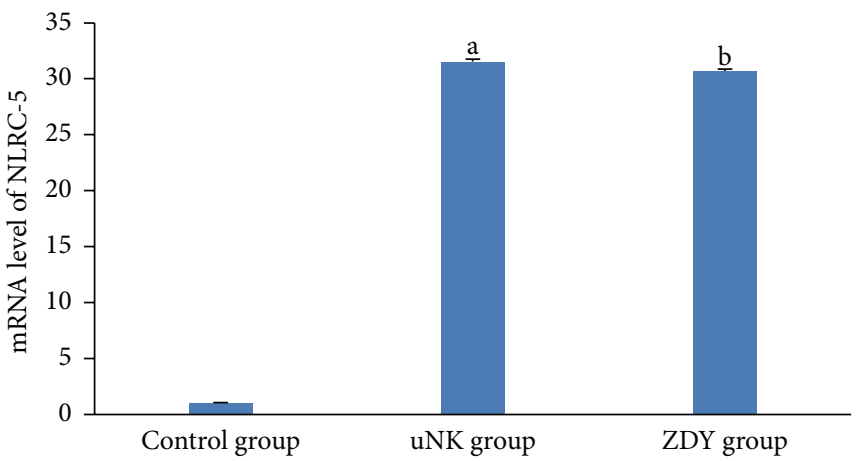

(d)

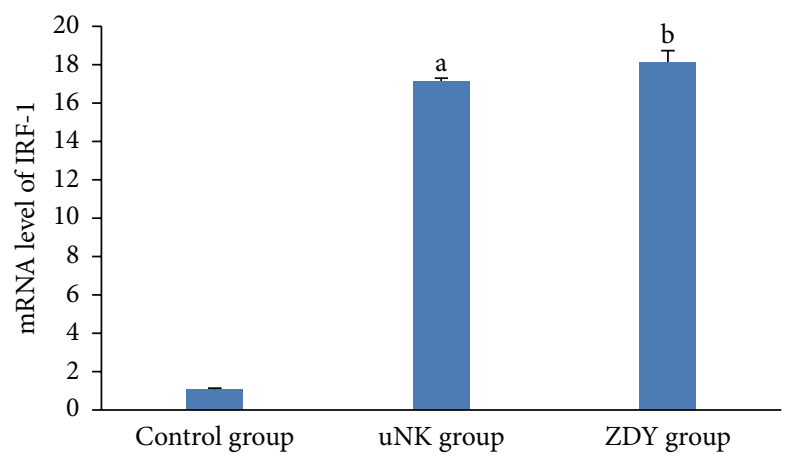

(e)

FIGURE 1: Transcription levels of (a) CXCL-10, (b) IL-15, (c) ICAM-1, (d) NLRC-5, and (e) IRF-1 determined by qRT-PCR. The relative fold changes are shown in Section 3. The qRT-PCR results were consistent with the microarray analysis. The data are expressed as means \pm SEM. ${ }^{\mathrm{a}} P<0.001$ for the comparison between the uNK and control groups; ${ }^{\mathrm{b}} P<0.001$ for the comparison between the ZDY and control groups.

(IL-33), were also altered. The levels of transcripts encoding molecules responsible for signaling, transport, structuration, and cell-cell adhesion were also downregulated. In addition, genes with various functions, such as ion binding, kinase, enzyme activity, and nucleotide metabolism, were found to be downregulated.

The microarray analysis identified 51 transcripts in epithelial cells that exhibited a statistically significant change in their median expression level (either upregulated or downregulated) in response to pretreatment with ZDY and treatment with the uNK cell-secretion medium compared with their level in response to treatment with uNK cellsecretion medium (Table 4). Of these genes, 33 were downregulated, and 18 were upregulated. The largest group of upregulated genes includes the following: enzyme asparagine synthetase (glutamine-hydrolyzing) (ASNS) and aldo-keto reductase family 1 member $\mathrm{Cl}$ (dihydrodiol dehydrogenase 1; 20-alpha (3-alpha)-hydroxysteroid dehydrogenase) (AKR1C1). The transcripts encoding molecules responsible for signal transduction, namely, aldo-keto reductase family 1 member C2 (dihydrodiol dehydrogenase 2; bile acid binding protein; 3-alpha hydroxysteroid dehydrogenase, type III) (AKR1C2) and structuration, such as talin 1 (TLN 1) and keratin 75 (KRT75), were also upregulated. The levels of transcripts encoding proteins that regulate transcription and ion binding, such as nuclear protein transcriptional regulator 1 (NUPR1) and S100 calcium binding protein A8 (S100A8), were also altered, and several genes with unknown function 


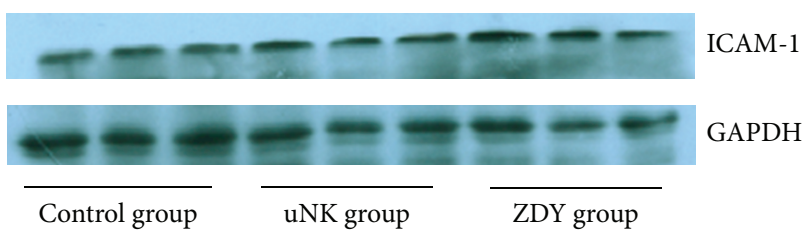

(a)

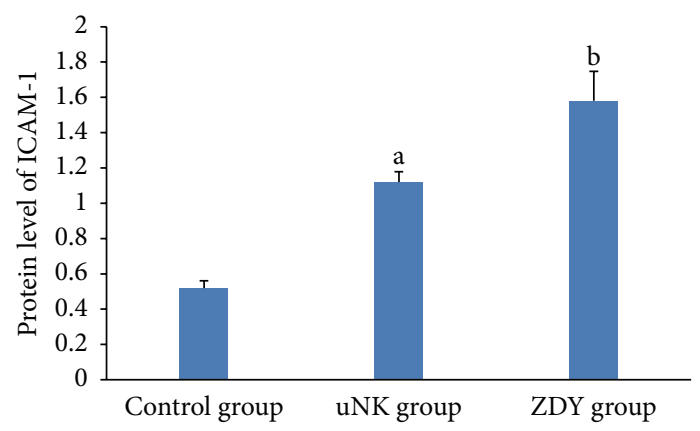

(b)

FIGURE 2: (a) Expression of endometrial ICAM-1 protein in endometrial epithelial cells. The GAPDH band was used as the internal loading control in each lane. (b) Comparison of the normalized expression intensity of endometrial ICAM-1 protein in the control, uNK, and ZDY groups. The data are expressed as means \pm SEM. ${ }^{a} P<0.01$ for the comparison between the uNK and control groups; ${ }^{\mathrm{b}} P<0.01$ for the comparison between the ZDY and control groups.

were found to be upregulated. The downregulated transcripts included only two genes of known function that were downregulated by more than 4fold: lamin B1 (LMNB1, a structural factor) and tankyrase, TRF1-interacting ankyrin-related ADP-ribose polymerase 2 (TNKS2, an enzyme activator). The genes that were downregulated by more than 2 fold included the genes encoding the cytokines chemokine (C-X-C motif) ligand 3 (CXCL3) and caprin family member 2 (CAPRIN2), the transporter component of the oligomeric golgi complex 5 (COG5), and various genes associated with transcription, kinase, ion binding, and nucleotide metabolism.

3.2. Quantitative Real-Time RT-PCR ( $q R T-P C R)$. To verify these changes, the transcript levels of the following genes were measured by qRT-PCR: CXCL-10, IL-15, ICAM-1, NLRC-5, and IRF-1 (Figure 1). The qRT-PCR results confirmed the substantial and significant changes in expression observed in the microarray analysis. Epithelial cells treated with the uNK cell-secretion medium showed increased expression levels of CXCL-10 (18.4-fold), IL-15 (11.7-fold), ICAM-1 (12.5-fold), NLRC-5 (31.5-fold), and IRF-1 (15.6-fold) (all $P<0.001$ ) compared with the control group.

We also confirmed that epithelial cells pretreated with ZDY and then treated with the uNK cell-secretion medium exhibited downregulated expression levels of CXCL-10 (0.9fold; $0.01<P<0.05$ ) and NLRC-5 (1.0-fold;0.01 $<P<$ 0.05 ) and upregulated levels of IL-15 (1.1-fold; $0.01<P<$ 0.05), ICAM-1(1.1-fold; $P>0.05$ ), and IRF-1 (1.1-fold; $P>$ $0.05)$ compared with epithelial cells treated with the uNK cell-secretion medium. However, none of these changes were significant.

3.3. Western Blot. To confirm these effects at the protein level, the amount of ICAM-1 was analyzed by western blot (Figure 2). Epithelial cells treated with the uNK cell-secretion medium showed a 2.1-fold $(P<0.01)$ increase in the expression of ICAM-1. However, the epithelial cells treated with ZDY and the uNK cell-secretion medium showed a 1.4fold increase $(0.01<P<0.05)$ in the expression of ICAM-1 compared with the epithelial cells treated with the uNK cellsecretion medium. Thus, there was no significant difference between the $\mathrm{uNK}$ and ZDY groups.

\section{Discussion}

Progesterone plays a central role in reproduction and is involved in implantation and pregnancy. When pregnancy occurs, high progesterone levels are critical not only for facilitating implantation but also for maintaining pregnancy by stimulating uterine growth $[20,21]$. Several observations suggest that uNK cells also play an important role in reproduction: (a) these cells are hormonally regulated because they increase in number during the luteal phase when implantation occurs [7], (b) these cells are present in early gestation at the time placental cells invade the maternal arteries [22], and (c) these cells are particularly abundant around trophoblast cells [23]. The proliferation of uNK cells is the foundation of their reproductive function. One of the mechanisms underlying the increase in uNK cell numbers is the stimulation of the proliferation of existing $\mathrm{uNK}$ cells by progesterone. In mouse uterine tissues, the significant upregulation in the decidual NK population is regulated by progesterone [24]. Because there are no progesterone receptors on uNK cells, it is hypothesized that the paracrine communication between $\mathrm{uNK}$ and epithelial cells participates in this process. In this study, we used the uNK cell-secretion medium to stimulate epithelial cells in an attempt to find the interaction and/or paracrine effects between these cells. The data obtained in the present study demonstrate that uNK cells have a significant effect on the gene expression in epithelial cells in the nonpregnant state, and these paracrine effects also have a profound effect on uNK proliferation.

The largest group of upregulated genes induced in epithelial cells by the soluble factors derived from uNK cells induced cytokines and immunological factors, including IL-15 and IL-15RA. IL-15 is critical for NK cell differentiation in mice and human lymphoid tissue $[25,26]$. IL-15 acts on precursor and immature NK cells. In humans, IL-15 transcription is more abundant during the secretory compared with the proliferative cycle phase, is maintained in early pregnancy, and localizes to the endothelium and decidual spiral arteries [27]. The correlative time strongly suggests that IL-15 participates in $\mathrm{uNK}$ cell proliferation and that IL-15 may also contribute to the localization of uNK cells. Our results show that uNK cells exhibit upregulated levels of both IL-15 and IL-15RA. This may activate a powerful proliferation loop because IL15 is presented by IL-15RA on epithelial cells to promote uNK proliferation. 


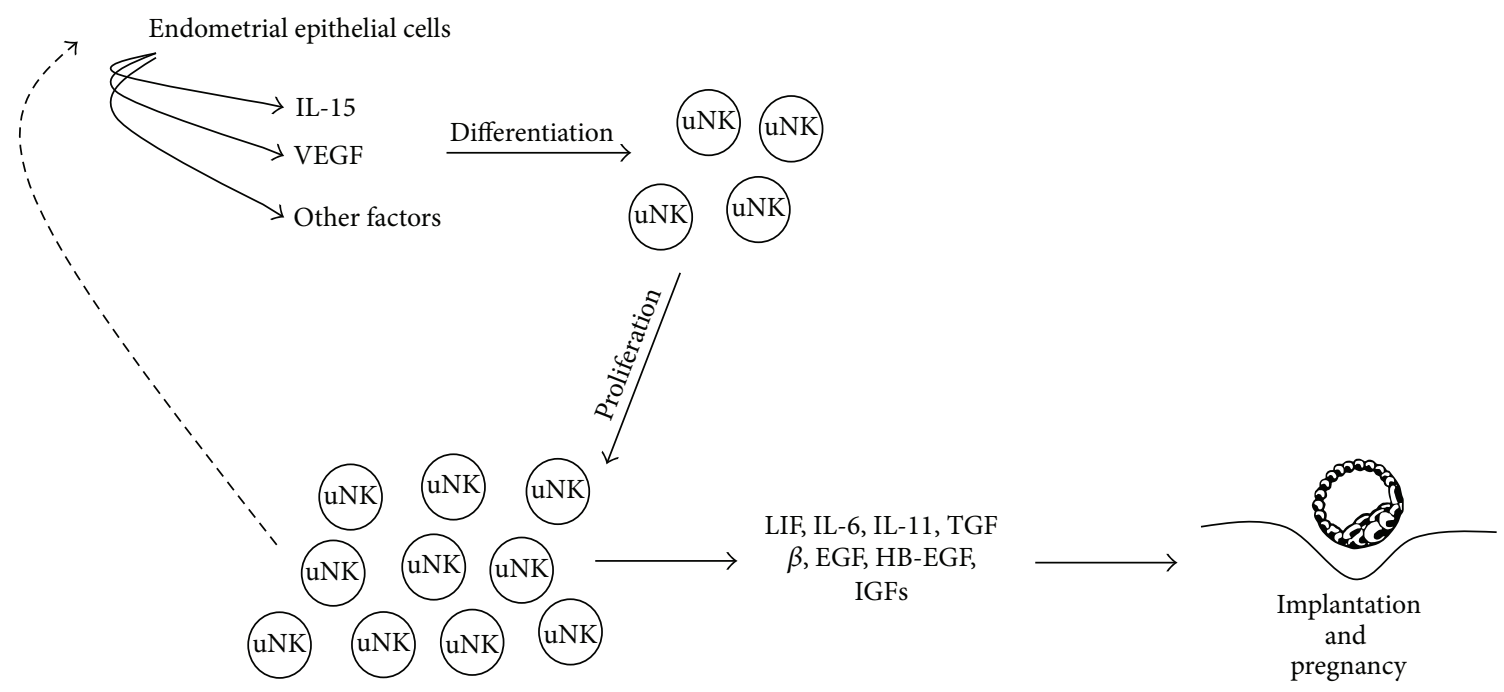

FIGURE 3: Model of the proliferation and function of uNK cells. During implantation and early pregnancy, the uNK paracrine signals stimulate endometrial epithelial cells to produce IL-15, VEGF, and other unidentified factors that may regulate uNK cell proliferation. The immune paracrine communication between uNK and endometrial epithelial cells may support implantation and trophoblast development.

There are temporal and quantitative features associated with the activities of uNK cells and trophoblast cells in uterine spiral artery maturation. There is evidence that IL-15 upregulates the level of VEGF-C mRNA expression, which suggests that uNK cells may play an important role in endometrial angiogenesis and regeneration [28]. In addition, CXCL-10 is involved in uNK cell production, directs the migration and invasion of CXCR1+, CXCR3+, CXCR4+, and CCR3+ trophoblast [12], and promotes angiogenesis in the placental bed [29]. Furthermore, in the absence of uNK cells, spiral artery extension is delayed, and the tunica media remain intact [30], and these studies are consistent with an angiogenic/vascular remodeling role for uNK cells [4, $12,31]$. We found some evidence that uNK cells promote changes in endometrial epithelial cells in the nonpregnant state. The level of VEGF-C, which is upregulated in epithelial cells by the uNK cell-secretion medium, increases markedly during implantation and early pregnancy [32]. Our data suggest that $\mathrm{uNK}$ may prime some of the decidualization changes that occur in epithelial cells prior to the onset of full decidualization.

The exact function of uNK cells has not yet been unequivocally determined, but it is known that these cells express a different cytokine profile compared with peripheral NK cells. For example, these cells express colony-stimulating factor (CSF), macrophage colony-stimulating factor (M-CSF), granulocyte-macrophage colony-stimulating factor (GMCSF), tumor necrosis factor alpha (TNF- $\alpha)$, interferon- $\gamma$ $($ IFN- $\gamma$ ), and leukemia inhibitory (LIF) [33, 34]. During human pregnancy, these cells are found in close proximity to the implantation site and in close contact with the infiltrating extravillous trophoblasts. Furthermore, uNK cells increase their numbers in early pregnancy due to hormonal dependence and exhibit close proximity to trophoblasts. Taken together, these data support the conclusion that uNK cells play an important role in the regulation for the maternal immune response for the control of implantation and trophoblast invasion during human pregnancy. The summary of the paracrine effects of uNK cells on the epithelial cells is shown in Figure 3.

In addition, this study provides the first demonstration of the paracrine communication between $\mathrm{uNK}$ and endometrial epithelial cells. Because our previous study showed that ZDY can improve the morphology of the endometrium in mice, we attempted to identify a relationship between the paracrine communication (uNK/epithelial cells) and the mechanism of action of ZDY. However, the majority of the up- and downregulated genes induced in the ZDY pretreated epithelial cells were of unknown function. To the best of our knowledge, there are no published studies on the effects of traditional Chinese medicine on the human endometrial paracrine communication. Our results suggest that ZDY may not regulate this process in vitro. ZDY may improve the morphology of the uterus through another mechanism.

\section{Conclusions}

Overall, this study provides the first detailed demonstration of the paracrine interaction between immune cells and epithelial cells in the endometrial environment. The findings indicate that these paracrine signals may contribute to uNK cell proliferation during implantation and early pregnancy. In addition, we failed to find evidence indicating that ZDY regulates the paracrine effects between uNK cells and epithelial cells in vitro.

\section{Conflict of Interests}

The authors declare that they have no conflict of interests. 


\section{Acknowledgments}

This project was supported by the Natural Science Foundation of China. The project number is 81173292 .

\section{References}

[1] J. Zhang, Z. Chen, G. N. Smith, and B. A. Croy, "Natural killer cell-triggered vascular transformation: maternal care before birth?” Cellular \& Molecular Immunology, vol. 8, no. 1, pp. 1-11, 2010.

[2] S. Quenby, H. Nik, B. Innes et al., "Uterine natural killer cells and angiogenesis in recurrent reproductive failure," Human Reproduction, vol. 24, no. 1, pp. 45-54, 2009.

[3] M.-J. Guimond, J. A. Luross, B. Wang, C. Terhorst, S. Danial, and B. A. Croy, "Absence of natural killer cells during murine pregnancy is associated with reproductive compromise in TgE26 mice," Biology of Reproduction, vol. 56, no. 1, pp. 169-179, 1997.

[4] G. E. Lash, S. C. Robson, and J. N. Bulmer, "Review: functional role of uterine natural killer ( $\mathrm{uNK}$ ) cells in human early pregnancy decidua," Placenta, vol. 31, pp. S87-S92, 2010.

[5] J. N. Bulmer, L. Morrison, M. Longfellow, A. Ritson, and D. Pace, "Granulated lymphocytes in human endometrium: histochemical and immunohistochemical studies," Human Reproduction, vol. 6, no. 6, pp. 791-798, 1991.

[6] H. Okada, T. Nakajima, M. Sanezumi, A. Ikuta, K. Yasuda, and H. Kanzaki, "Progesterone enhances interleukin-15 production in human endometrial stromal cells in vitro," Journal of Clinical Endocrinology \& Metabolism, vol. 85, no. 12, pp. 4765-4770, 2000.

[7] A. King, V. Wellings, L. Gardner, and Y. W. Loke, "Immunocytochemical characterization of the unusual large granular lymphocytes in human endometrium throughout the menstrual cycle," Human Immunology, vol. 24, no. 3, pp. 195-205, 1989.

[8] S. Verma, S. E. Hiby, Y. W. Loke, and A. King, "Human decidual natural killer cells express the receptor for and respond to the cytokine interleukin 15," Biology of Reproduction, vol. 62, no. 4, pp. 959-968, 2000.

[9] T. A. Henderson, P. T. K. Saunders, A. Moffett-King, N. P. Groome, and H. O. D. Critchley, "Steroid receptor expression in uterine natural killer cells," Journal of Clinical Endocrinology and Metabolism, vol. 88, no. 1, pp. 440-449, 2003.

[10] O. Gubbay, H. O. D. Critchley, J. M. Bowen, A. King, and H. N. Jabbour, "Prolactin induces ERK phosphorylation in epithelial and CD56+ natural killer cells of the human endometrium," Journal of Clinical Endocrinology \& Metabolism, vol. 87, no. 5, pp. 2329-2335, 2002.

[11] A. Germeyer, A. M. Sharkey, M. Prasadajudio et al., "Paracrine effects of uterine leucocytes on gene expression of human uterine stromal fibroblasts," Molecular Human Reproduction, vol. 15, no. 1, pp. 39-48, 2009.

[12] J. Hanna, D. Goldman-Wohl, Y. Hamani et al., "Decidual NK cells regulate key developmental processes at the human fetalmaternal interface," Nature Medicine, vol. 12, no. 9, pp. 10651074, 2006.

[13] A. S. Crimmel, C. S. Conner, and M. Monga, "Withered Yang: a review of traditional Chinese medical treatment of male infertility and erectile dysfunction," Journal of Andrology, vol. 22, no. 2, pp. 173-182, 2001.

[14] C. Qian, J. Zhe, L. Qiu-dan, C. Ying, and L. Nan, "Affection of Zidan decoction containing serum on endometrial receptivity in uterine immunity environment," Guo Ji Zhong Yi Zhong Yao Za Zhi, vol. 2012, no. 3, pp. 220-223, 2012.

[15] D. L. Carlone and V. Rider, "Embryonic modulation of basic fibroblast growth factor in the rat uterus," Biology of Reproduction, vol. 49, no. 4, pp. 653-665, 1993.

[16] P. Viganò, B. Gaffuri, E. Somigliana, M. Infantino, M. Vignali, and A. M. Di Blasio, "Interleukin-10 is produced by human uterine natural killer cells but does not affect their production of interferon- $\gamma$," Molecular Human Reproduction, vol. 7, no. 10, pp. 971-977, 2001.

[17] S. Verma, S. E. Hiby, Y. W. Loke, and A. King, "Human decidual natural killer cells express the receptor for and respond to the cytokine interleukin 15," Biology of Reproduction, vol. 62, no. 4, pp. 959-968, 2000.

[18] M. S. Diamond, D. E. Staunton, A. R. De Fougerolles et al., "ICAM-1 (CD54): a counter-receptor for Mac-1 (CD11b/CD18)," Journal of Cell Biology, vol. 111, no. 6, pp. 3129-3139, 1990.

[19] S. D. Marlin and T. A. Springer, "Purified intercellular adhesion molecule-1 (ICAM-1) is a ligand for lymphocyte functionassociated antigen 1 (LFA-1)," Cell, vol. 51, no. 5, pp. 813-819, 1987.

[20] C. L. Clarke and R. L. Sutherland, "Progestin regulation of cellular proliferation," Endocrine Reviews, vol. 11, no. 2, pp. 266301, 1990.

[21] J. Dinny Graham and C. L. Clarke, "Physiological action of progesterone in target tissues," Endocrine Reviews, vol. 18, no. 4, pp. 502-519, 1997.

[22] J. Bulmer, P. Johnson, and D. Bulmer, "Leukocyte populations in human decidua and endometrium," in Immunoregulation and Fetal Survival, T. C. Gill and T. Wegmann, Eds., pp. 111-134, Oxford University Press, New York, NY, USA, 1987.

[23] Y. Loke, Human Implantation: Cell Biology and Immunology, Cambridge University Press, Cambridge, UK, 1995.

[24] Y. S. Choe, C. Shim, D. Choi, C. S. Lee, K. K. Lee, and K. Kim, "Expression of galectin-1 mRNA in the mouse uterus is under the control of ovarian steroids during blastocyst implantation," Molecular Reproduction and Development, vol. 48, no. 2, pp. 261-266, 1997.

[25] M. K. Kennedy, M. Glaccum, S. N. Brown et al., "Reversible defects in natural killer and memory CD8 T cell lineages in interleukin 15-deficient mice," Journal of Experimental Medicine, vol. 191, no. 5, pp. 771-780, 2000.

[26] W. E. Carson, J. G. Giri, M. J. Lindemann et al., "Interleukin (IL) 15 is a novel cytokine that activates human natural killer cells via components of the IL-2 receptor," Journal of Experimental Medicine, vol. 180, no. 4, pp. 1395-1403, 1994.

[27] K. Kitaya, J. Yasuda, I. Yagi, Y. Tada, S. Fushiki, and H. Honjo, "IL-15 expression at human endometrium and decidua," Biology of Reproduction, vol. 63, no. 3, pp. 683-687, 2000.

[28] X. F. Li, D. S. Charnock-Jones, E. Zhang et al., "Angiogenic growth factor messenger ribonucleic acids in uterine natural killer cells," Journal of Clinical Endocrinology \& Metabolism, vol. 86, no. 4, pp. 1823-1834, 2001.

[29] A. Moffett-King, "Natural killer cells and pregnancy," Nature Reviews Immunology, vol. 2, no. 9, pp. 656-663, 2002.

[30] D. Chakraborty, M. A. Karim Rumi, T. Konno, and M. J. Soares, "Natural killer cells direct hemochorial placentation by regulating hypoxia-inducible factor dependent trophoblast lineage decisions," Proceedings of the National Academy of Sciences of the United States of America, vol. 108, no. 39, pp. 16295-16300, 2011. 
[31] S. D. Smith, C. E. Dunk, J. D. Aplin, L. K. Harris, and R. L. Jones, "Evidence for immune cell involvement in decidual spiral arteriole remodeling in early human pregnancy," The American Journal of Pathology, vol. 174, no. 5, pp. 1959-1971, 2009.

[32] G. E. Lash, B. Schiessl, M. Kirkley et al., "Expression of angiogenic growth factors by uterine natural killer cells during early pregnancy," Journal of Leukocyte Biology, vol. 80, no. 3, pp. 572-580, 2006.

[33] P. P. Jokhi, A. King, A. M. Sharkey, S. K. Smith, and Y. W. Loke, "Screening for cytokine messenger ribonucleic acids in purified human decidual lymphocyte populations by the reverse-transcriptase polymerase chain reaction," Journal of Immunology, vol. 153, no. 10, pp. 4427-4435, 1994.

[34] S. Saito, K. Nishikawa, T. Morii et al., "Cytokine production by CD16-CD56(bright) natural killer cells in the human early pregnancy decidua," International Immunology, vol. 5, no. 5, pp. 559-563, 1993. 


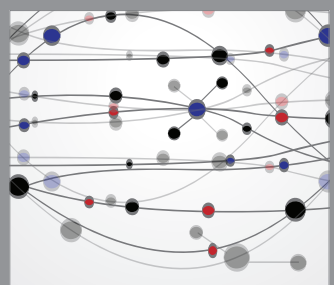

The Scientific World Journal
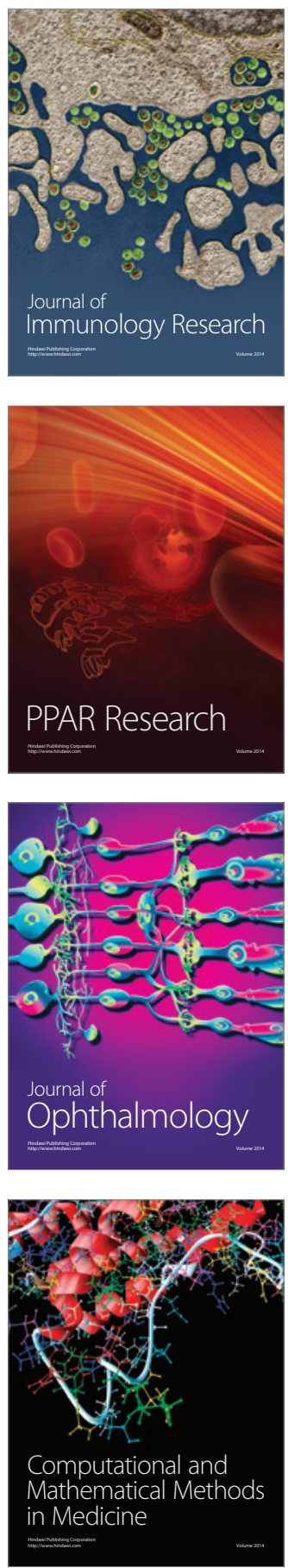

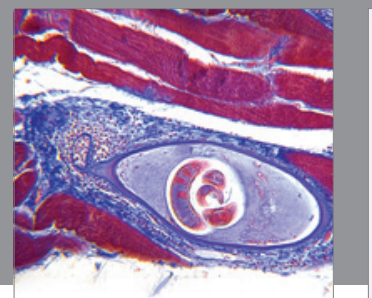

Gastroenterology

Research and Practice
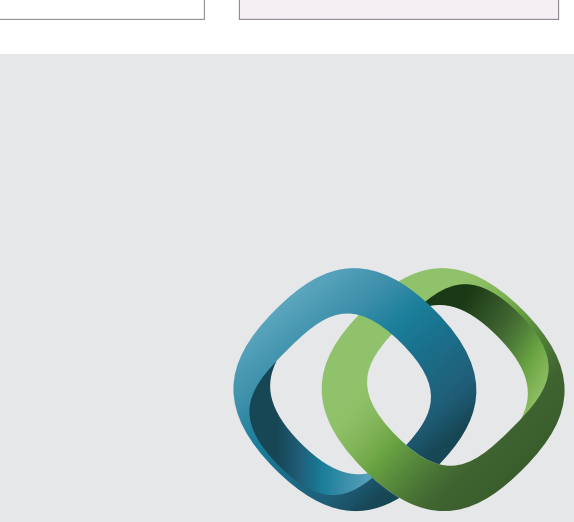

\section{Hindawi}

Submit your manuscripts at

http://www.hindawi.com
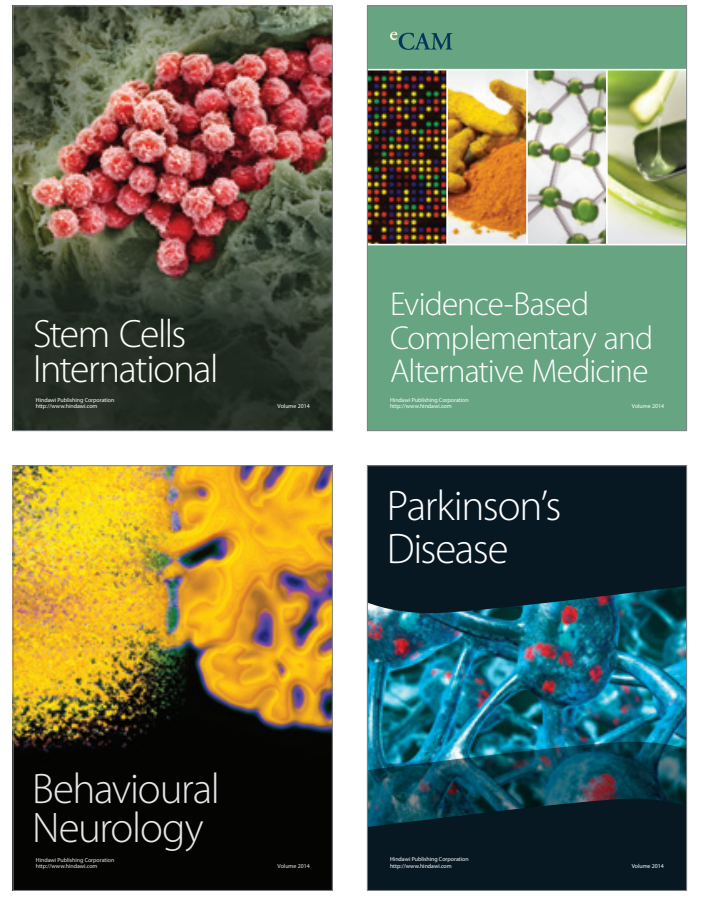
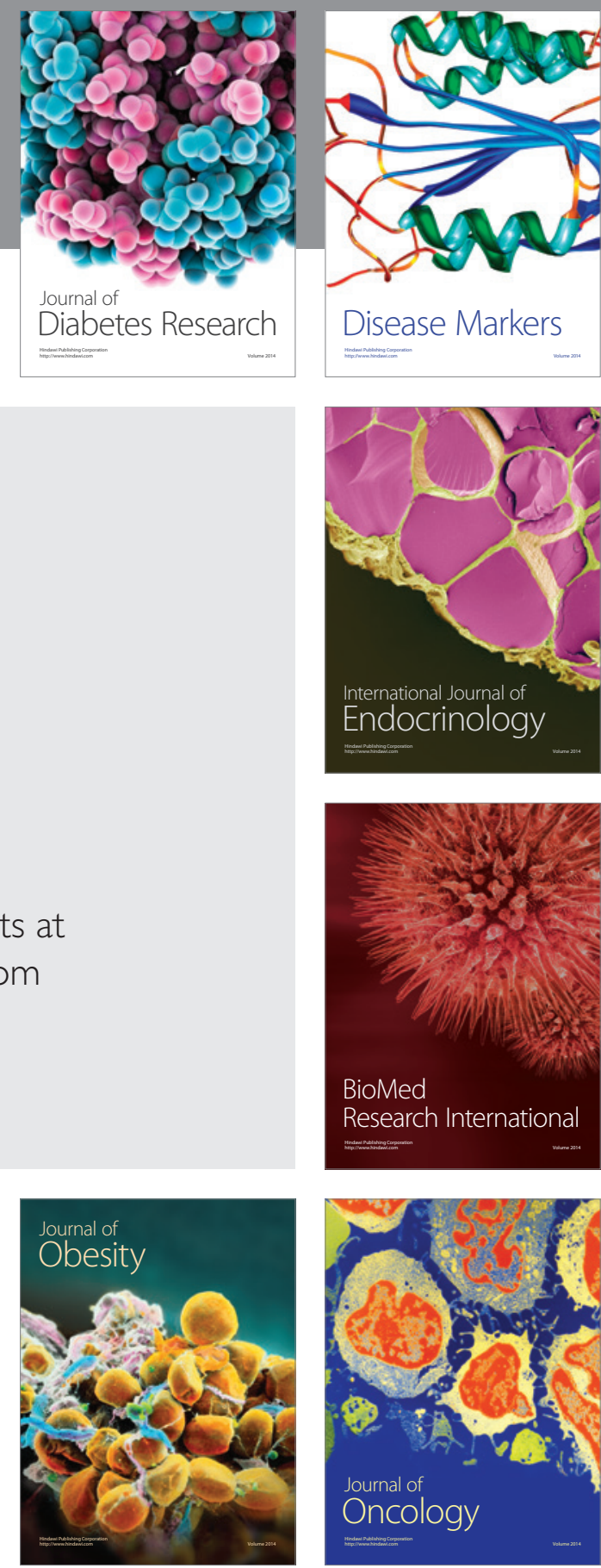

Disease Markers
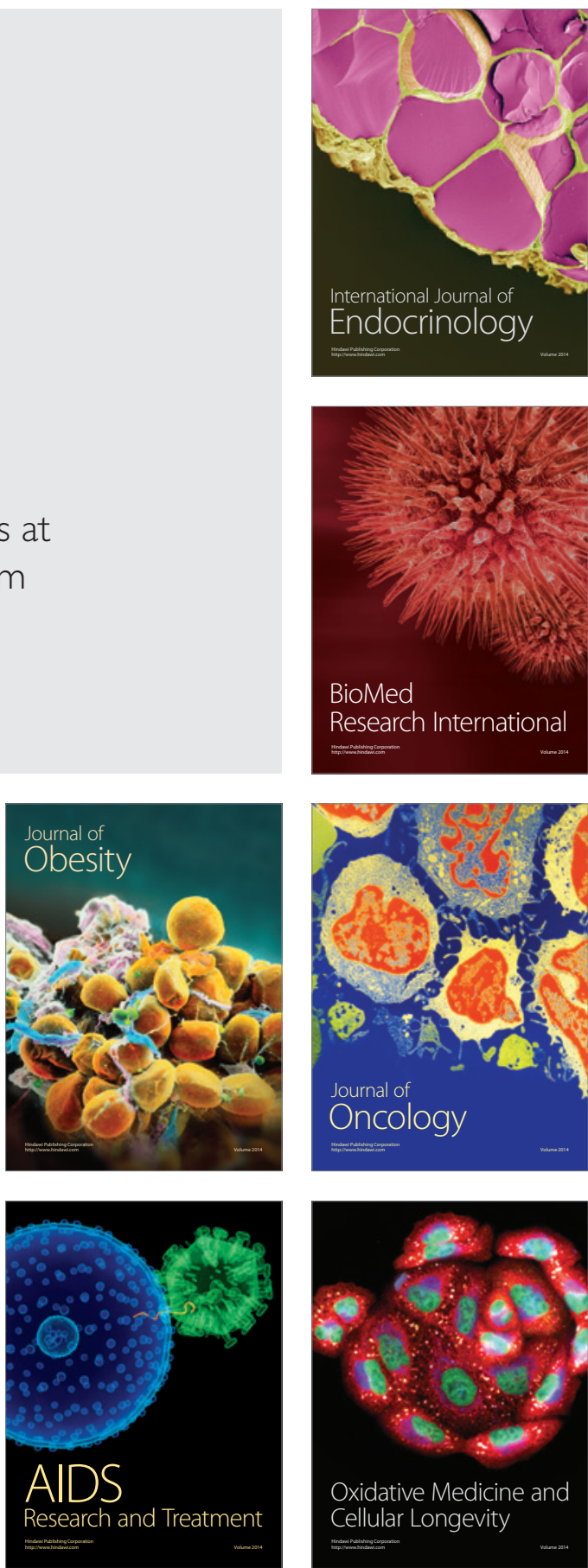